\title{
Children and disabilities: what we call them, think and feel about them
}

\author{
Ricardo Berridi, M.D. ${ }^{a}$
}

\begin{abstract}
Disability is a problem that affects more and more children and adolescents. But in the course of our graduate and postgraduate education, we have received practically no training in this regard. A pediatrician is the primary care physician of every child and adolescent, and the above-mentioned lack of training becomes a hurdle in the care provided to children with disabilities. Our idea of diversity is clearly determined by our culture and the social and family environment where we grew up, and is highly influenced by our human and extracurricular development rather than by our medical training. Every course involved in professional training should include a subject on disability. As pediatricians, we should reflect on how we see children with disabilities.

Key words: children with disabilities, community integration, professional training.
\end{abstract}

http:/ /dx.doi.org/10.5546/aap.2016.eng.464

\section{Magnitude of the problem}

The World Health Organization (WHO) in June 2011, reported that more than $15 \%$ of the world population has some form of disability; this accounts for more than 1 billion people, more than 300 million children, and most live in the under-developed world, in some of the poorest countries in the world. ${ }^{1}$ It is known that most poor people are children and youth, and most children and youth are poor. Poverty, hunger, and malnutrition, as the end result, are among the most common causes of intellectual disability.

In Argentina, approximately $12.9 \%$ of the population has some form of disability, and one in every five households is affected by this problem. Out of $8,738,530$ households, there is a disabled individual in 1,802,051, and 4,463,156 people live with a person who has a disability. ${ }^{2}$

a. Division of Clinical Pediatrics of Hospital "Dr. Noel H. Sbarra", La Plata. SAP Task Force on Disabilities.

E-mail address:

Ricardo Berridi, M.D., ricardoberridi@ciudad.com.ar

Funding: None.

Conflict of interest: None.

Received: 12-11-2015

Accepted: 03-28-2016
The following is evidenced in The State of the World's Children $2013^{3}$ report by the United Nations Children's Fund (UNICEF), which dealt specifically with children with disabilities:

- Eighty percent of children with disabilities live in under-developed countries, and $90 \%$ of them are cut off from the minimum health, education and social services to which they are entitled.

- Children with disabilities are more likely to live in poverty.

- Worldwide, less than $2 \%$ of children with disabilities attend school. In Argentina, approximately $30 \%$ of these children attend school.

- Girls with disabilities are at a higher risk for sexual abuse, sexually transmitted infections and AIDS given that they are believed to have no sex life and are therefore left out of sex education programs.

- As long as children with disabilities remain excluded, many international initiatives, such as the Millennium Development Goals and Education for All, will not be achieved.

According to the numbers described by the First Argentine Consensus on Cerebral Palsy: the Role of Perinatal Care, published in the Archivos Argentinos de Pediatría, in 2000, among all births occurred every year in Argentina (700,000$750,000)$ :

- 5\%, i.e. 35,000 newborn infants, will have a congenital anomaly.

- $10 \%$, i.e. 70,000 newborn infants, will be born preterm.

- $0.25 \%$, i.e. 1500 newborn infants, will have chronic non-progressive encephalopathy.

- $0.4 \%$, i.e. 2800 newborn infants, will have an intellectual disability.

- $0.15 \%$, i.e. 1070 newborn infants, will have Down syndrome.

\section{Pediatricians and children with disabilities}

Too many children and adolescents with disabilities are the target of shame, disdain, discrimination, and abuse.

As pediatricians, we are naturally the primary care physicians of all children and adolescents. 
This may sound platitudinous, but it is not if we consider the everyday reality of children with disabilities, who in general do not even have a pediatrician, as expected.

By "all," we mean all, not most but all, with no exclusions whatsoever. Once this occurs, childhood may be considered diverse. Otherwise, it's "us" versus "them", the "abnormal", the "weird", the "others", the "special" versus "us, the normal ones".

Maybe in such diverse setting we should think of many "childhoods" instead of just one "childhood", and recognize that there is probably not just one "universe" but "multiple universes" that should live together in harmony.

Also, and as a result of the lack of training on disabilities during our medical graduate and postgraduate education, when faced with children with disabilities in our office, we replicate our social knowledge, translate our prejudices, discriminate, and move away from empathy, which we do feel when there is no disability involved.

Everything starts with the words and definitions we use: "The wrong words lead to wrong plans, and these, to wrong actions" said Bertolt Brecht. When we use adjectives like mentally retarded, incapacitated, handicapped, different, challenged and a long list of other terms, we position ourselves in front of children with disabilities with a lack of knowledge on how to handle their problem, even though considering the term "retarded" to refer to them is a definition in itself. Not to mention the terms used many times by physicians when talking about hospitalized children with multiple disabilities, such as the "water-carrying pipe system" in bed 7 or the "member of the plant kingdom" in bed 20.

Concepts and paths are closely related. "The heart of what you believe in is in the root of what you do," used to say wise men to their disciples in the Renaissance. Establishing names is a powerful mechanism. Nietzsche ${ }^{5}$ already referred to what truth meant: "a sum of human relations, which have been enhanced, transposed, and embellished poetically and rhetorically, and which after long use seem firm, canonical, and obligatory to a people".

Disability is not a scientific concept; in any case, as proposed by Foucault, "every society generates the mechanisms through which it perceives differences and how to deal with them." For this reason, when referring to people as weak, retarded, deficient, crippled, mutilated, handicapped, imbecile, etc., the terms and images used reveal the social symbolism in which they were created.

"It is socially reckless to bring a child into the world knowing that he or she has a severe genetic disorder in the era of prenatal diagnosis." More than $50 \%$ of people agreed with this statement in South Africa, Belgium, Greece, Portugal, the Czech Republic, Hungary, Poland, Russia, Israel, Turkey, China, India, Thailand, Brazil, Colombia, Cuba, Mexico, Peru, and Venezuela. In the USA, $26 \%$ of geneticists, $55 \%$ of primary care physicians, and $44 \%$ of patients also agreed. ${ }^{6}$

The phrase may even sound reasonable, but... who is in charge of defining "severe"? Does severe mean the same in every social environment, society, population, family? Is Down syndrome "severe"? What about hydrocephalus? And severe left ventricle hypoplasia? What about a child with a neuromuscular disorder who will die in the medium term? What about agenesis of an arm? And agenesis of a hand? And agenesis of a finger? What if it is a girl?

In many locations around the world, at present, pregnancies are terminated if the fetus is female. As we see, it is difficult to establish what "severe" means, and therefore acceptance of the terms described above is alarming.

A child with a disability, like any other child, is single and unique; they "are not" their diagnosis, they "are not" the Down's, they "are not" the cerebral palsied, just like we do not call ordinary children the "asthmatics", "cardiacs", or "celiacs". Children and adolescents "are not" their disability; they are children and adolescents who develop, like everyone else, in their own uniqueness but have more trouble understanding reality; they have the same problems as other children, they need to develop their abilities, and require their environment to provide the same things provided to other children and adolescents; they need to achieve their maximum level of autonomy and self-reliance possible; in the end, they behave like any other child according to their upbringing conditions. In any case, children have a disability, they are not their disability and do not suffer from a disability. A vast majority of children with disabilities live happily, or as happy as any other child with no disability would in the same setting.

Anthropology and the study of societies demonstrate that cultural beliefs in a social environment at a specific time in history have an influence on how the problem of disability is interpreted, from the perspective of both individuals and healthcare providers. Such 
cultural paths make us learn socially accepted manners of disease, confer the origin of disease to different causes, and expect certain treatment responses and attitudes from healthcare teams.

Actually, for a long time, social psychology has been dealing with stigma, a misused term, especially in the medical field, confused with sign or symptom or sometimes used pejoratively to denote a sign or symptom typical of a disability. A stigma describes the situation of a person who has become disqualified for full social acceptance. The term originated in Greek to refer to the marks on the body that represented something unusual and bad in terms of the moral standing of the person who had them. No stigmata should be described during the physical exam of children; they have signs and symptoms.

Sometimes, based on commiseration and sympathy, we discriminate, even positively, e.g. when we describe children as having "special abilities," being "everlasting" or "pure of heart," and the list goes on, but these terms only highlight differences, taking a stand of "them" versus "us" and noting that "us" does not include "them." What makes a special ability? Breathing underwater? Flying? Children with disabilities have no special abilities, they have a disability. They are not special or different; they are children who face a series of difficulties in a dissimilar manner, but they are part of the same universe as all children.

Our language, our attitudes, our perspective and the way we relate to children with disabilities are very important to adequately fulfill our obvious role as primary care physicians of all children. This is not just a matter of linguistics or semantics; it clearly represents our prejudices and the perspective we have grasped culturally; it is an integral part of us.

A society that does not discriminate admits diversity and creates an inclusive environment for all of its members. It is not just better for children and adolescents with disabilities; it is better for all of its members. We should not fight for inclusion out of sympathy towards people with disabilities, but for all of us.

\section{Epilogue}

The task of raising a child with a disability is, for the family, more difficult than raising a child with no disabilities. At this point, the role of pediatricians takes on its full meaning because we are responsible for coordinating multiple healthcare actions related to that child's needs, and attempting to achieve agreement with the family and assign them a relevant role. Families are our "partners" in this task; we should consult them, adapt therapies to the family dynamics, act as enablers of action for greater effectiveness, and thus avoid futile efforts, which many times take place due to the shortfalls of the primary care physician's non-delegable duties.

In the framework of diversity, the only thing in common to all human beings is that we are all different, unique and incomparable, and in the setting of the Convention on the Rights of the Child ${ }^{7}$ and the Convention of the Rights of Persons with Disabilities, ${ }^{8}$ these are children with a health impairment or deficit, living in a specific social environment, which is decisive at the time of defining their disability.

It is clear that, like most of the things that relate to our professional practice, our concept of diversity is defined by our culture and the social and family environment where we grew up.

In terms of disability, the problem is magnified by the lack of training on the subject during our graduate and post-graduate education. As a result, the way we see children with disabilities is conditioned somehow by our human and extracurricular development, rather than by our medical education. Such lack of training is a limitation when attempting to meet the needs of children with disabilities and their families; such shortfall should push us towards the integration of courses on disability in every stage of our professional training.

"The best thing about the world is the number of worlds it has; luckily, we are different; luckily, we are diverse," once stated Eduardo Galeano. ${ }^{9}$

Also, like Caetano Veloso sang: "Nobody is normal when you get close".

\section{Acknowledgments}

I would like to thank María Fernanda Astigarraga, B.S., Head of the Library of Hospital Noel H. Sbarra, for her valuable collaboration.

\section{BIBLIOGRAPHY}

Ameijeira A. Infancia y maltrato: el futuro imperfecto. Noticias Metropolitanas 2004;30:3-5.

- Egea García E, Sarabia Sánchez A. Clasificaciones de la OMS sobre discapacidad. Boletín del Real Patronato sobre Discapacidad 2001;50:15-30. [Accessed on: February $\left.16^{\text {th }}, 2016\right]$. Available at: http://www.um.es/discatif/ METODOLOGIA/Egea-Sarabia_clasificaciones.pdf.

- Greenfield SA. Brain function. Arch Dis Child 2003;88(11): 954-5.

- Lejarraga H. La atención pediátrica de pacientes crónicos, una práctica necesaria. Arch Argent Pediatr 2006;104(1):62-3. 
- Organización Mundial de la Salud. Clasificación Internacional del Funcionamiento de la Discapacidad y de la Salud. Madrid: IMSERSO; 2001.

- ScorgieK,Sobsey D. Transformational outcomes associated with parenting children who have disabilities. Ment Retard 2000;38(3):195-206.

- Van Dyck PC, Kogan MD, McPherson MG, Weissman GR, et al. Prevalence and characteristics of children with special health care needs. Arch Pediatr Adolesc Med 2004;158(9): 884-90.

- Verdugo MA, Jordán de Urríes FB. Hacia una nueva concepción de la discapacidad. Salamanca: Amarú; 1999. Wolbring G. Ciencia, tecnología y la DED (discapacidad, enfermedad, defecto). Polis 2002;1(3). [Accessed on: February $\left.17^{\text {th }}, 2016\right]$. Available at: http://polis.revues. org/7686.

\section{REFERENCES}

1. World Health Organization. World report on disability. Geneva: WHO; 2011. [Accessed on: February 16 ${ }^{\text {th }}, 2016$ ]. Available at: http://www.who.int/disabilities/world_ report/2011/report.pdf?ua $=1$.

2. Argentina. Instituto Nacional de Estadística Y Censos. Población en viviendas particulares, población con dificultad o limitación permanente y prevalencia de la dificultad o limitación permanente, según sexo y grupo de edad: año 2010. In Censo Nacional de Población, Hogares y Viviendas 2010. Buenos Aires: INDEC; 2013. [Accessed on: February 16 $\left.{ }^{\text {th }}, 2016\right]$. Available at: http:// www.indec.gov.ar/definitivos_bajarArchivoNacionales. asp?idc $=16 \&$ arch $=x \& c=2010$.
3. UNICEF. Estado mundial de la infancia 2013: niñas y niños con discapacidad. Nueva York: UNICEF; 2013. [Accessed on: February $\left.16^{\text {th }}, 2016\right]$. Available at: http:/ / www.unicef. org/spanish/sowc2013/files/SPANISH_SOWC2013_Lo_ res.pdf.

4. Academia Nacional de Medicina, Asociación Argentina de Perinatología, Asociación de Obstétricas Municipales, Federación Argentina de Sociedades de Obstetricia y Ginecología, et al. Consenso Argentino sobre Parálisis Cerebral: rol del cuidado perinatal. Arch Argent Pediatr 2000;98(4):253-7.

5. Nietzsche F. Sobre verdad y mentira en sentido extramoral. [Accessed on: February 16 $\left.{ }^{\text {th }}, 2016\right]$. Available at: http:// www.henciclopedia.org.uy/autores / Friedrich $\% 20$ Nietzsche/Verdad\%20mentira.htm.

6. Wertz D. Eugenics Is alive and well: a survey of genetic professionals around the world. Sci Context 1998;11(3-4): 493-510.

7. Naciones Unidas. Asamblea General. Convención sobre los Derechos del Niño. 1989. [Accessed on: February $16^{\text {th }}$, 2016]. Available at: http://www.unicef.org/argentina/ spanish/7.-Convencionsobrelosderechos.pdf.

8. Naciones Unidas. Convención sobre los derechos de las personas con discapacidad y protocolo facultativo. 2006. [Accessed on: February 16 $\left.{ }^{\text {th }}, 2016\right]$. Available at: http:// www.un.org/disabilities/documents/convention/ convoptprot-s.pdf.

9. Arellano Ortiz F. Eduardo Galeano: “América Latina cuenta con grandes reservas de dignidad". Pueblos: Revista de Información y Debate 2005. [Accessed on: February $17^{\text {th }}$, 2016. Available at: http:/ / www.revistapueblos.org/old/ spip.php?article306. 